\title{
A tüdő nekrotizáló sarcoid granulomatosisa
}

\author{
Zombori-Tóth Noémi dr. ${ }^{1}$ - Ugocsai Katalin dr. ${ }^{1}$ \\ Vincze Árpád dr. ${ }^{2}$ - Furák József dr. ${ }^{3}$. Tiszlavicz László dr. ${ }^{4}$ \\ Iványi Béla dr. ${ }^{4}$ - Zombori Tamás dr. ${ }^{4}$ \\ ${ }^{1}$ Csongrád-Csanád Megyei Mellkasi Betegségek Szakkórháza, Deszk \\ ${ }^{2}$ Békés Megyei Központi Kórház, Gyula \\ ${ }^{3}$ Szegedi Tudományegyetem, Általános Orvostudományi Kar, Sebészeti Klinika, Szeged \\ ${ }^{4}$ Szegedi Tudományegyetem, Általános Orvostudományi Kar, Patológiai Intézet, Szeged
}

\begin{abstract}
A nekrotizáló sarcoid granulomatosis a granulomatosus pulmonalis angitisek közé tartozó, ritka kórkép. Egyesek a sarcoidosis variánsának, mások primer pulmonalis vasculitisnek tartják. A kórkép klinikai és patológiai jellegzetességeit két eset bemutatásával ismertetjük. A 20 éves nőbeteg sürgősséggel került pulmonológiai osztályra száraz köhögés, jobb oldali, mély belégzéssel összefüggő mellkasi fájdalom és láz miatt, a 63 éves férfi beteget pedig pneumoniát követő kontroll-mellkasröntgenfelvételen látott elváltozás kivizsgálása során észlelték. Az autoimmun panel vizsgálata, a mikrobiológiai tesztek mindkét betegnél negatívnak bizonyultak, a légzésfunkciós vizsgálat és a bronchoszkópos vizsgálat nem talált eltérést. A mellkas-CT-felvételen lágyrész-denzitású nodulusok látszottak egyoldali dominanciával, a folyamatot nem kísérte a hilusi nyirokcsomók szimmetrikus megnagyobbodása. A nodulusok szövettani vizsgálata vált indokolttá, melyet videoasszisztált torakoszkópos tüdőreszekciós mintavétellel biztosítottak. Mikroszkóposan a tüdőparenchymában gócos nekrózisokat, a környezetükben el nem sajtosodó epitheloid sejtes granulomatosus gócokat, az átfutó artériákban pedig granulomatosus arteritist láttak; a klinikai adatok figyelembevételével a tüdő nekrotizáló sarcoid granulomatosisa diagnózisát állították fel. A tüdőbetegség mindkét betegnél egy év alatt spontán regrediált. Az irodalom adatait és az eseteket összegezve, a tüdő nekrotizáló sarcoid granulomatosisában mikrobiológiai vizsgálatokkal nem igazolható tüdőfertőzés, és az immunológiai kivizsgálás sem tár fel szisztémás autoimmun betegséget; a diagnózis a klinikai kép és a képalkotó vizsgálatok alapján indikált szövettani vizsgálattal állítható fel. A betegség szteroidkezelésre jól reagál, de előfordul spontán regresszió is, az utóbbira láttunk példát. Bár az entitás átmenetet képez a nekrotizáló vasculitisek és a sarcoidosis között, egyre több érv szól amellett, hogy a sarcoidosis spektrumába tartozik.
\end{abstract}

Orv Hetil. 2021; 162(38): 1541-1547.

Kulcsszavak: differenciáldiagnosztika, granulomatosus pulmonalis angitis, nekrotizáló sarcoid granulomatosis, sarcoidosis

\section{Pulmonary necrotizing sarcoid granulomatosis}

Necrotizing sarcoid granulomatosis is a rare entity currently classified as a subtype of granulomatous pulmonary angiitis. It is considered to be either a variant of sarcoidosis or a primary pulmonary angiitis. Two cases are demonstrated to present its clinical and pathological features. A 20 -year-old female patient was admitted to the department of pulmonology with dry cough, right-sided chest pain during hyperventilation and fever. A 63-year-old male patient was observed with a right-sided lesion on chest X-ray after pneumonia. In both cases, autoimmune panel examination, microbiology tests, spirometry function test and bronchoscopy were unremarkable. Chest CT scans have revealed nodules with soft-tissue density without bilateral hilar lymphadenopathy. In order to clarify the diagnosis, video-assisted thoracoscopic resection (biopsy) was performed. Microscopically, parenchymal focal necrosis with adjacent to non-caseating granulomas and granulomatous angiitis were detected. In both cases, spontaneous remission occurred within a year. Histological examination - integrated with clinical data and radiological tests' results - is the gold standard form of evaluation to confirm necrotizing sarcoid granulomatosis; furthermore, exclusion of pneumonia and autoimmune diseases are also required. The disease responds well to corticosteroids; moreover, spontaneous remission is often reported, as it happened in both cases. Necrotizing sarcoid granulomatosis is a transition between necrotizing vasculitides and sarcoidosis; although more and more evidence appears supporting the fact that necrotizing sarcoid granulomatosis may belong to the spectrum of sarcoidosis. 
Keywords: differential diagnosis, granulomatous pulmonary angiitis, necrotizing sarcoid granulomatosis, sarcoidosis

Zombori-Tóth N, Ugocsai K, Vincze Á, Furák J, Tiszlavicz L, Iványi B, Zombori T. [Pulmonary necrotizing sarcoid granulomatosis]. Orv Hetil. 2021; 162(38): 1541-1547.

(Beérkezett: 2021. március 3.; elfogadva: 2021. március 20.)

\begin{abstract}
Rövidítések
$\mathrm{ACE}=($ angiotensin-converting enzyme $)$ angiotenzinkonvertáló enzim; ALP = (alkaline phosphatase) $)$ alkalikus-foszfatáz; $\mathrm{ANCA}=($ antineutrophil cytoplasmic antibody) antineutrophil cytoplasmaticus antitest; $\mathrm{CRP}=\mathrm{C}$-reaktív protein $; \mathrm{CT}=(\mathrm{com}-$ puted tomography) komputertomográfia; GGT = gamma-glutamil-transzferáz; GPA = granulomatosis polyangitisszel; NSG $=$ nekrotizáló sarcoid granulomatosis; PAS = (periodic acid Schiff) perjódsavas Schiff-reakció; SBO = sürgősségi betegellátó osztály; VATS = (video-assisted thoracic surgery) videoaszszisztált torakoszkópos sebészet
\end{abstract}

A nekrotizáló sarcoid granulomatosist (NSG) az Osztrák-Magyar Monarchiában (Sztrij, Galícia; ma Ukrajna) született, majd az Egyesült Államokba kivándorolt Averill Abraham Liebow (1911-1978) patológus írta le 1973-ban [1]. Liebow a granulomatosissal járó pulmonalis angitis öt formáját különítette el: Wegenergranulomatosis (granulomatosis polyangitisszel - GPA), limitált Wegener-betegség, lymphomatoid granulomatosis, bronchocentrikus granulomatosis, valamint NSG [1]. Az NSG három fó ismérve: a szövettani vizsgálat során észlelt sarcoidszerú granulomák vasculitisszel és nekrózissal; a radiológiailag megfigyelhető multiplex pulmonalis nodulusok hilusi nyirokcsomó-megnagyobbodás nélkül; valamint a kedvező klinikai lefolyás: a betegség minimális terápiával kezelhető, vagy nem igényel specifikus kezelést $[2,3]$. Liebow első leírása óta vitatják, hogy a kórkép a sarcoidosis egyik altípusa vagy pedig önálló primer pulmonalis vasculitis $[3,4]$. A kórképról szerzett tapasztalatainkat két eset bemutatása kapcsán az alábbiakban adjuk közre.

\section{Esetismertetések}

\section{Elsö eset}

A 20 éves nőt (foglakozása: egyetemi hallgató) sürgőséggel vették fel a Csongrád-Csanád Megyei Mellkasi Betegségek Szakkórházának pulmonológiai osztályára. Előtte sürgősségi betegellátó osztály (SBO) észlelte száraz köhögés, jobb oldali, mély belégzéssel összefüggő mellkasi fájdalom, hőemelkedés, majd láz tüneteivel. Fizikális vizsgálattal jelentős eltérés nem állt fenn. Az SBO-n készített laborvizsgálat emelkedett C-reaktív protein szintet (CRP: $68,5 \mathrm{mg} / \mathrm{l})$, májfunkciós értékeket (ALP: $228 \mathrm{U} / 1, \mathrm{GGT}$ : $107 \mathrm{U} / \mathrm{l})$, relatív $(0,59 \mathrm{G} / \mathrm{l})$ és abszolút $(7,8 \%)$ eosinophil granulocyta számot, illetve D-dimer- $(3,94 \mathrm{mg} / \mathrm{l})$ értéket igazolt. Posteroanterior mellkas-röntgenvizsgálatot és mellkasi angio-komputertomográfiát (angio-CT) végeztek. A mellkas-röntgenvizsgálat során mindkét tüdőben elszórtan számtalan, 0,5-1,5 cm-es kerekárnyék látszódott, melyek a bázis felé egyre sûrübben fordultak elő jobb oldali dominanciával. A mellkasi angio-CT-felvétel ( $1 / A$ ábra) kizárta a pulmonalis embolia lehetôségét, azonban mindkét oldalon, a tüdőben elszórtan 6-32 mm-es, kissé szabálytalan kontúrú, lágyrész-denzitású képleteket írt le. A legnagyobbak a jobb tüdő bázisán, dorsalisan a mellhártyával összefüggve helyezkedtek el. Több helyen tejüvegszerú homályok vették körül a laesiókat. A beteg benntartózkodása során Legionella pneumophila, illetve Streptococcus pneumoniae infekció irányában vizeletmintát, illetve féregpete kimutatására székletmintát vettek, negatív eredménnyel. Mind a Mantoux-próba, mind a QuantiFERON-teszt negatív eredményt adott. Bronchoszkópia során hörgőmosást végeztek citológiára, bakteriológiára, gombára, direkt Koch-vizsgálatra, Mycobacterium-tenyésztésre, Mycobacterium-PCR-re, vírus és Pneumocystis jirovecii kimutatására, ezek azonban mind negatív eredménnyel zárultak. A vérvétel során Aspergillus galaktomannán, Echinococcus granulosus, Toxocara canis és Cryptococcus neoformans antigéneket, illetve antitesteket szintén nem sikerült kimutatni. A vérvétel során immunpanel- (antineutrophil cytoplasmaticus antitest [ANCA], mieloperoxidáz elleni antitest és proteináz-3 elleni antitest) és tumormarker-vizsgálatra is sor került, ezek szintén negatív eredménnyel zárultak. A kivizsgálás során extrapulmonalis manifesztáció gyanúja miatt hasi ultrahangvizsgálat, nőgyógyászati, reumatológiai, endokrinológiai és fül-orr-gégészeti kivizsgálás is történt, érdemi eltérés nélkül. Az onkoteam-bemutatáson a team diagnosztikus, szövettani mintavétel céljából videoasszisztált torakoszkópos tüdőreszekció (VATS) mellett foglalt állást.

A szövettani vizsgálat során lymphangiocentrikusan jól formált, epitheloid sejtes granulomák, a környezetükben lévő pumonalis artériákban granulomatosus vasculitis látszott. Az érintett erekben súlyos intimalis fibrosis alakult ki, amely a lumen elzáródásához vezetett, így az általuk ellátott tüdőrészek koagulációs nekrózisa jött létre $(1 / B-C$ ábra). Perjódsavas Schiff-reakcióval (PAS) gombát, Gram-festéssel baktériumot, Ziehl-Neelsenfestéssel mycobacterialis infekciót kimutatni nem tudtak. 

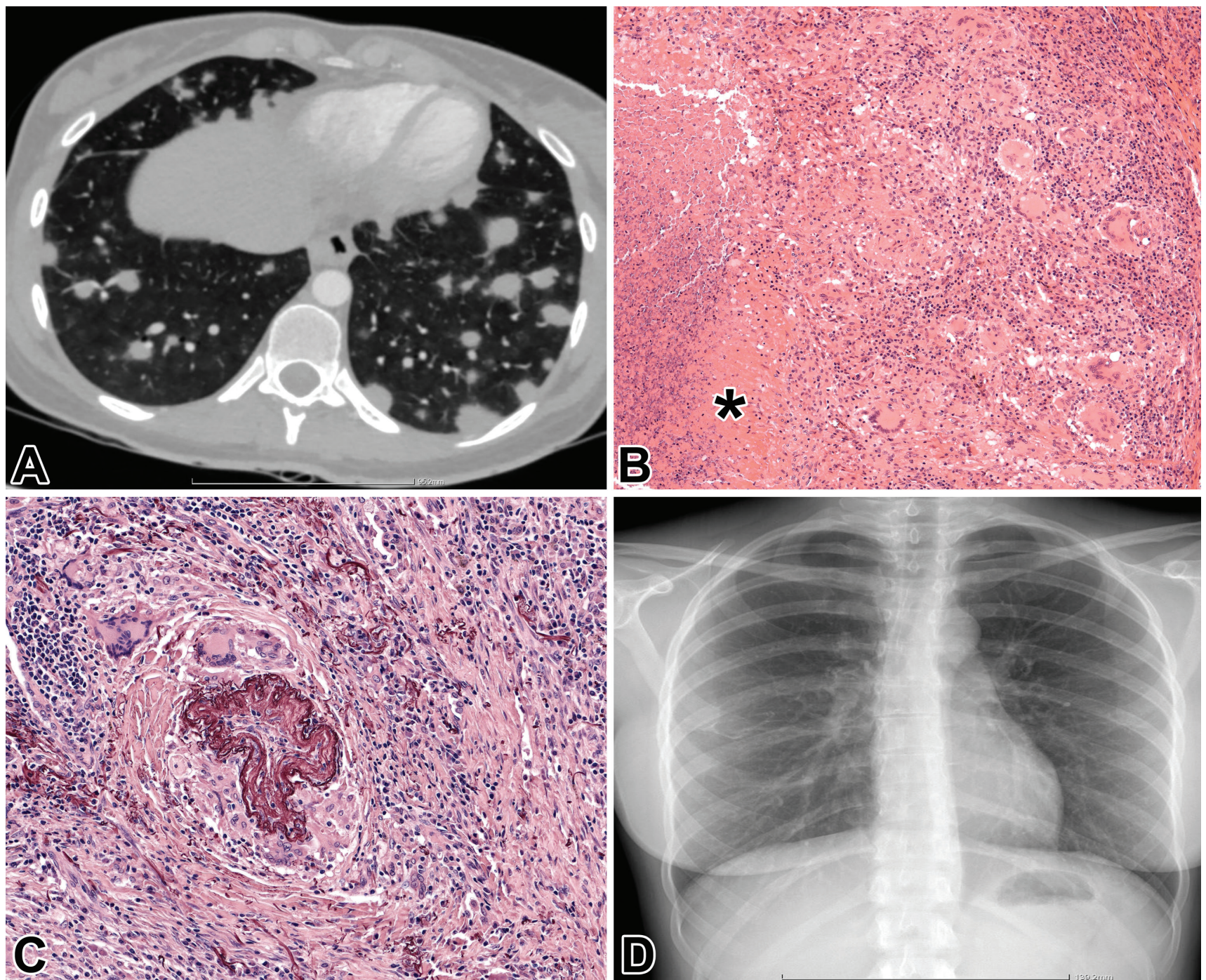

1. ábra

A: A mellkas-CT-felvételen mindkét tüdőben elszórtan számtalan, néhol a mellhártyával összefüggést mutató kerekárnyék igazolható; B: Közepes nagyítású szövettani képen a nekrózist ${ }^{*}$ ) granulomatosus reakció veszi körbe (HE, 10×); C: A közepes nagyítású szövettani ábrán lumenobstrukcióval járó, granulomatosus vasculitis észlelhető óriássejtekkel (orcein, 20×); D: A kontroll-mellkasröntgenfelvételen a kerekárnyékok teljes remissziója igazolható

$\mathrm{CT}=$ komputertomográfia; $\mathrm{HE}=$ hematoxilin-eozin

Mivel a laborvizsgálatok a fertőzéses eredetet, a szisztémás autoimmun betegségek lehetőségét, továbbá maguk a szöveti jellegzetességek a GPA lehetőségét nem támogatták, az NSG diagnózisát állították fel.

Az idő múlásával a beteg panaszmentes lett, és a javasolt kontroll mellkasi CT-felvétel elhagyása mellett döntött. A sebészi reszekció után két évvel később készített mellkas-röntgenfelvételen ( $1 / \mathrm{D}$ ábra) a korábban leírt multiplex kerekárnyékok remissziója látszott.

\section{Második eset}

A 63 éves férfi beteget (foglalkozása: mentőápoló) korábban pneumonia miatt észlelték, melyre antibiotikumterápiát kapott. A kontrollvizsgálatok során érdemi panaszt nem említett. A kontroll-mellkasröntgenfelvételen jobb oldalon a szív-rekesz szögletben diónyi inhomogén árnyék ábrázolódott. Ennek kivizsgálására mellkas-CTfelvétel készült (2/A ábra), mely jobb oldalon, a 4-es és a 8-as szegmentum határán, 40 mm átmérőjü, szabálytalan alakú, lágyrész-denzitású képletet igazolt, környezetében póklábszerú nyúlványokkal és diszkrét fátyolozottsággal. Azonos oldalon, subpleuralisan egy 6,6 mm átmérőjü nodularis képlet tűnt szembe. A mediastinumban elszórtan néhány, 5-6 mm átmérőjü nyirokcsomó ábrázolódott. A mellkas-CT-felvételen látott eltérések felvetették a primer tüdődaganat és nyirokcsomó-metasztázisának gyanúját, így további kivizsgálás céljából a 'staging' (stádiummeghatározó) vizsgálatok komplettálását és a bronchoszkópos vizsgálat elvégzését javasolták. A csontszcintigráfia során malignitásra utaló szcintigráfiás jel nem mutatkozott. A bonchoszkópia során a szubszegmensszintig áttekinthető hörgőkben daganatra gyanús eltérések egyik oldalon sem álltak fenn. A légzés- 
funkció-vizsgálat során kóros eltérést nem detektáltak. Az onkoteam-referálás VATS-lobectomia elvégzését javasolta.

A szövettani vizsgálat során nekrózist okozó granulomatosus vasculitis $(2 / B-C a ́ b r a)$ igazolódott, amelyet sarcoidosisra emlékeztető nodularis infiltrátum kísért. A korábbi esethez hasonlóan elvégzett speciális festések nem igazoltak kórokozót. A szövettani kép, valamint a laboratóriumi és a klinikai adatok alapján az NSG kórisméjét állították fel. Ezek után a beteg reumatológiai kivizsgálása extrapulmonalis manifesztációt és sarcoidosisra utaló laboratóriumi eltéréseket nem mutatott. Laborértékeiben az emelkedett lipidértékeken kívül kóros nem mutatkozott. Reumatológiai-immunológiai szempontból terápia indítását nem tartották indokoltnak. A beteg az illetékes kórház tüdőgyógyászati ambulanciáján kontroll-mellkasröntgenvizsgálatokon vett részt 3 havonta, melyeken a posztoperatív röntgenfelvételekkel összevet- ve radiomorfológiai változás nem tûnt szembe, kiújulás nem igazolódott. Fél évvel a mútét után enyhén csökkent terhelhetősége miatt a deszki Csongrád-Csanád Megyei Mellkasi Betegségek Szakkórházában kivizsgálták: a légzésfunkció-vizsgálat során nem mutatkozott érdemi eltérés. Laboreredményeiben jelentős eltérés nem mutatkozott, mellkas-röntgenfelvételén a korábbi felvételekkel összehasonlítva kiújulás nem tűnt szembe (2/D ábra). Tekintettel a sarcoidosisra specifikus tünetek hiányára, valamint a relapsus hiányára, szteroidkezelést nem indítottak.

\section{Megbeszélés}

Az NSG Liebow szerinti fó ismérvei a granulomatosuslymphocytás vasculitis, amely érelzáródáshoz és következményes koagulációs nekrózishoz vezet az ellátott tüdőállományban, valamint a „sarcoid-like” granulomák
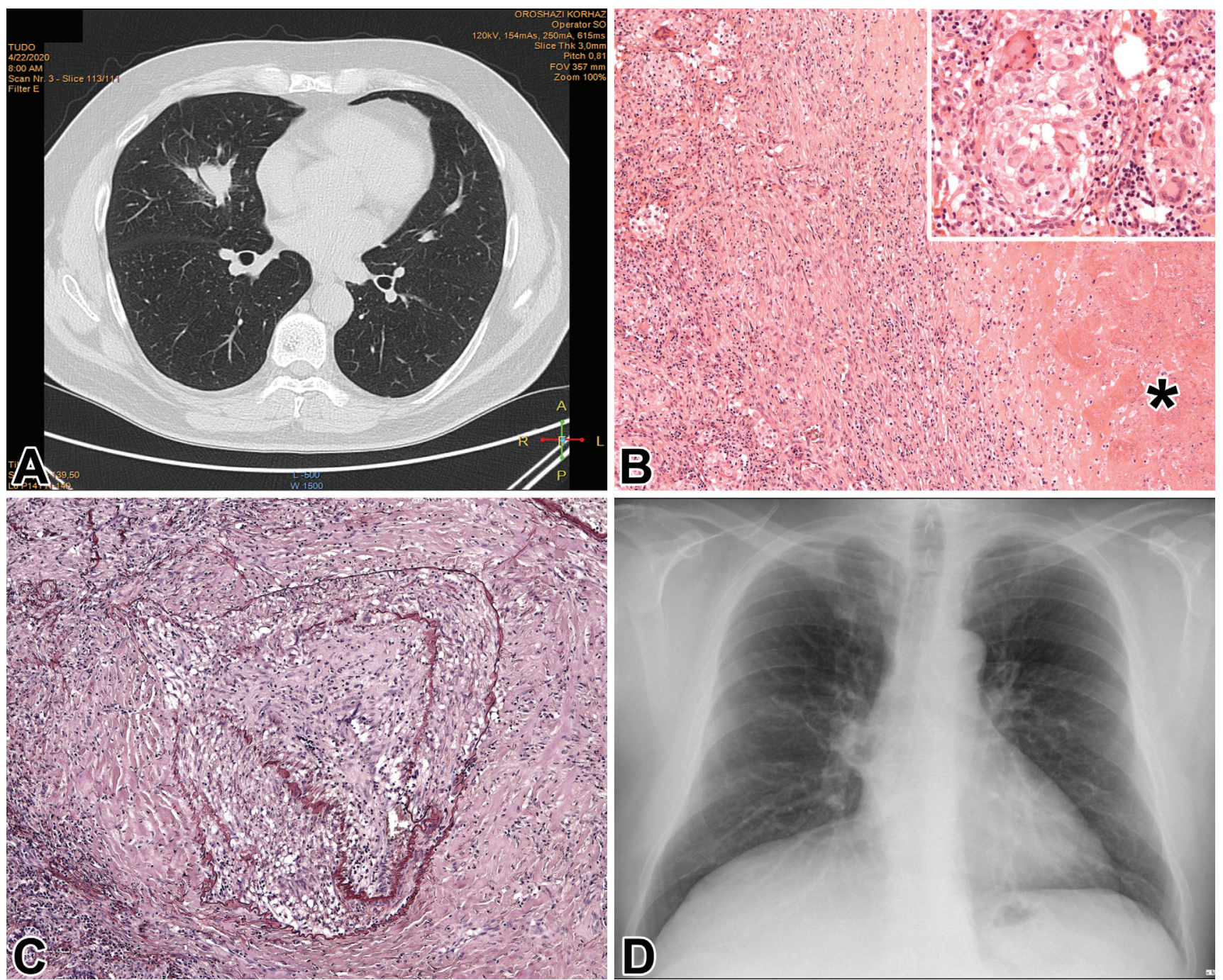

2. ábra

A: Mellkas-CT-vizsgálat. Jobb oldalon a 4-es és a 8-as szegmentum határán $40 \mathrm{~mm}$ átmérőjú, szabálytalan alakú, lágyrész-denzitású képlet mutatkozik, környezetében póklábszerú nyúlványokkal. B: Közepes nagyítású szövettani képen a nekrózist ( *) granulomatosus reakció veszi körbe (HE, 10×). Az inzert képen a laesiótól távolabb észlelt „sarcoid-like” granulomára látunk példát (HE, 40×). C: A képen az elasztikus rostokat destruáló granulomatosus vasculitis mutatható ki érelzáródással (orcein, $10 \times$ ). D: A kontroll-mellkasröntgenvizsgálat alkalmával kiújulás nem túnt szembe

$\mathrm{CT}=$ komputertomográfia; $\mathrm{HE}=$ hematoxilin-eozin 
jelenléte [1]. Az NSG incidenciáját illetően, mivel ritka betegség, nem áll pontos adat rendelkezésre a szakirodalomban. Az NSG nókben gyakrabban fordul elő (férfi : nő arány: 1 : 1,7), és leginkább a negyedik évtized közepén jelentkezik [5]. Az NSG egyes klinikopatológiai sajátságait az 1. táblázat mutatja be. A betegségben pulmonalis, valamint szisztémás tünetek egyaránt előfordulnak. A leggyakoribb tünetek a láz, a mellkasi fájdalom, a fogyás, az éjszakai izzadás, a kimerültség, a száraz köhögés és a nehézlégzés. Ritkábban véres köpet is előfordulhat. Az NSG eseteinek mintegy 14\%-ában fordulnak elő extrapulmonalis manifesztációk, amelyek a leggyakrabban a központi idegrendszert, a szemet és a bőrt érintik [5].

A képalkotó vizsgálatokkal a pulmonalis laesiók lehetnek szoliterek, multiplexek, egy- vagy kétoldaliak. A beteg kivizsgálása során a mellkas-röntgenfelvételen egy vagy több kerekárnyék jelenik meg, melyek az esetek egy részében összefüggnek a pleurával. A CT-felvételeken szabálytalan alakú, elmosódott szélü, lágyrész-denzitású képletek jelenhetnek meg. A radiológiai vizsgálatok az esetek egy részében daganat gyanúját keltik, és ez a mellkassebész segítségével végzett szövettani mintavétel irányába tereli a diagnosztikai folyamatot $[5,6]$.

NSG esetén nem állnak fenn specifikus laboratóriumi eltérések. Az NSG kórisméje reumatológiai és fertőzéses kórképek kizárásával történik. Az elvégzendő laborvizsgálatok közé tartozik az autoantitestek kimutatása (például antikardiolipin-antitestek, reumafaktor, ANCA, antinukleáris antitest), a hepatitis A-, B- és C-szerológia, valamint a Mycobacterium tuberculosis és gombák által okozott infekciók mikrobiológiai vizsgálata. Az NSG sajátsága, hogy a gyulladásos paraméterek (süllyedés, CRP) szintje általában nem emelkedett, és az angiotenzinkonvertáló enzim (ACE) szintje is alacsony a szérumban [7].

Az NSG szövettani diagnózisát - a klinikum, a radiológiai és a laborvizsgálati eredmények ismeretében - elsősorban mütéti reszekátumból lehet felállítani. Mint az 1. táblázat bemutatja, a tüdőben előforduló, nekrotizáló granulomatosus laesiók differenciáldiagnosztikai spektruma igen széles. Mivel ezen kórképek hátterében a leggyakrabban fertőzéses betegségek állnak, számos speciális festés készül rutinszerűen. Ziehl-Neelsen-festéssel mycobacteriumok (elsősorban Mycobacterium tuberculosis), PAS-reakcióval vagy Grocott-festéssel gombák jelenléte igazolható. Az utóbbiak közül Európában leginkább a histoplasmosis és a cryptococcosis fordul elö. Fontos kiemelni, hogy a fenti speciális festések a kórokozó irányában specifikusak, de viszonylag alacsony szenzitivitásúak. Ezáltal a negatív eredmény önmagában nem zárja ki a fertőzéses eredetet. Az elasztikus rostokat láthatóvá tevő orceinfestéssel $(1 / C, 2 / C$ ábra) az erek falának elasztikusrost-feltöredezése mutatható ki, ami segíti a granulomatosus vasculitis felismerését [8].
A klasszikus sarcoidosis és az NSG morfológiája nagyrészt hasonló. Mindkét kórképben jellemző a jól formált granulomák jelenléte, illetve jelen lehet a nekrózis és a granulomatosus vasculitis is. Klasszikus sarcoidosisban azonban a nekrózis inkább az összeolvadó granulomák közepén alakul ki. Ezen elhalás inkább pontszerü, és kialakulásában az ischaemia játszik szerepet. Klasszikus sarcoidosisban a granulomatosus vasculitis nem vezet kiterjedt tüdőelhaláshoz [9].

Noha a GPA további differenciáldiagnosztikai lehetőséget jelent, szövettani jellegzetességei némileg eltérőek. GPA esetén nekrotizáló, nem granulomatosus vasculitis észlelhető, amelynek kialakulásában elsősorban neutrophil granulocyták vesznek részt. A nekrózis gyakran térképszerú és ún. „dirty” jellegú, amelyet a neutrophilekből felszabadult magtörmelék okoz. GPA-ban a roszszul formált, nem „sarcoid-like” granulomák és az óriássejtek a nekrózis környezetében és nem az erek falában észlelhetők. A GPA kizárását támogathatja továbbá az ANCA-negativitás is $[10,11]$.

Rosen 2015-ben publikált közleményében összefoglalta a szakirodalomban addig megjelent, követési adatokkal is rendelkező NSG-eseteket [5]. Elemzéséból kiemelendő, hogy a csak sebészileg kezelt NSG-esetek 38\%-ában komplett vagy inkomplett regresszió alakult ki, míg a kortikoszteroidterápiában részesült betegek esetében a komplett vagy inkomplett regresszió aránya $81 \%$ volt. Igen kis számú esetben alkalmaztak kombinált kortikoszteroid- és immunszuppresszív (például ciklofoszfamid-) kezelést, amelynek esetleges hatásosságára vonatkozóan - az alacsony esetszám miatt - következtetéseket nem tudtak levonni. Szigorú értelemben egy esetben igazoltak NSG miatti halálozást, melynek során központi idegrendszeri érintettség alakult ki. Emellett előfordult még NSG miatt végzett lobectomia és ciklofoszfamid-kezelés szövődményeként kialakult pneumonia, valamint nem kórismézett NSG mellett létrejött tüdőgyulladás is [5].

Már Liebow is megfogalmazta, hogy a betegség átmenetet képez a nekrotizáló vasculitisek és a sarcoidosis között. Egyes közlemények szerzői [4, 5, 10] a betegséget a sarcoidosis spektrumába sorolják, míg mások [3, 12] inkább önálló entitásnak tartják. A sarcoidosis és az NSG klinikai, radiológiai és patológiai jellegzetességei jelentős átfedést mutatnak (1. táblázat). Mindkét kórképben női predominancia észlelhető, és középkorúakban jelentkezik - habár az NSG némileg idősebbek körében alakul ki. Mindkét betegségnél előfordul extrapulmonalis manifesztáció, illetve mediastinalis lymphadenopathia, ugyanakkor a sarcoidosis esetében ezek gyakoribbak. A morfológiai hasonlóságok között említendő a jól formált granulomák, a különböző mértékú nekrózis és vasculitis jelenléte. Az utóbbi két sajátság kiterjedtségében észlelhető jelentősebb eltérés. Míg a sarcoidosis esetében a vasculitis jelenlétét $48 \%$ és $69 \%$ közé teszik a különböző 


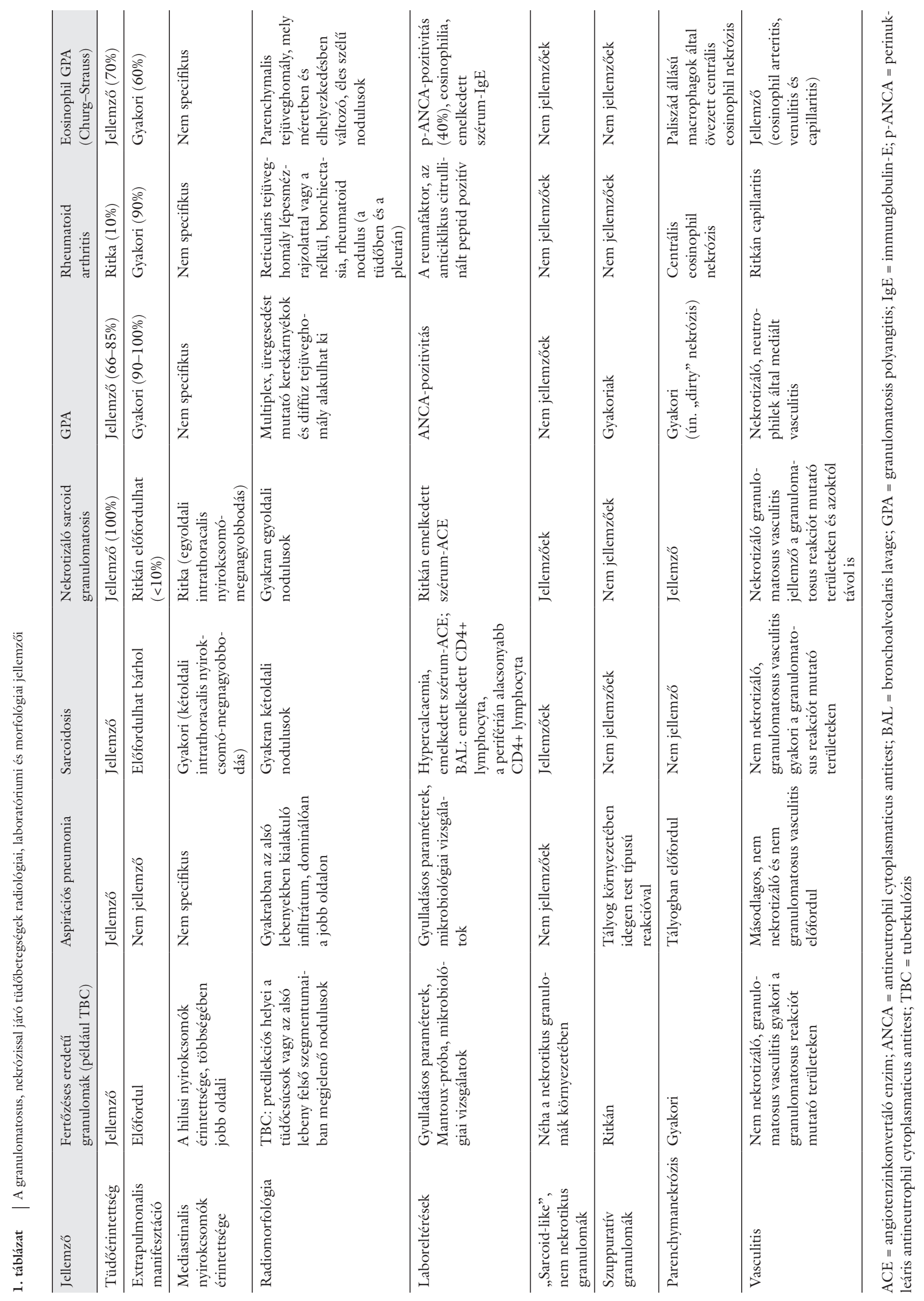


közlemények [13-15], az NSG esetében ez definíció szerint mindig jelen van. Jelentős különbség figyelhető meg a két betegség diagnosztikus megközelítése között is. Rosen vizsgálatai alapján az NSG diagnózisát csaknem mindig mútéti anyagból állították fel, míg ez az arány a sarcoidosisban mintegy 33\%. Az utóbbi esetben egyre elterjedtebb a kisebb megterheléssel végezhető bronchusbiopszia és a VATS mediastinalis nyirokcsomó-mintavétel [16]. A kisebb mintákban a fokálisan észlelhetó vasculitis, illetve a nekrózis felismerése nehezebb, így ezen jellegzetességek alulreprezentáltak lehetnek sarcoidosis esetén. A klinikumot illetően további közös sajátság az akár specifikus kezelés nélküli kedvező kimenetel. Tény azonban, hogy NSG-vel igazolt betegek körében a spontán regresszió ritkábban fordul elő, illetve ezen esetek szteroidra jobban reagálnak. A betegség definiálása óta eltelt közel 50 évben folyamatosan gyúlő klinikopatológiai adatok alapján - az itt bemutatott, a sarcoidosissal jelentősen átfedő sajátságok miatt - egyre inkább a sarcoidosis egyik kiterjedt, nekrózissal és vasculitisszel jellemezhető manifesztációjának tartják $[4,5,10]$.

\section{Következtetés}

Esetismertetésünkkel szeretnénk felhívni a figyelmet erre a ritka, egyre inkább a sarcoidosis speciális formájának tartott interstitialis tüdőbetegségre, melynek leginkább a kizárásos alapú kórisméje jelent kihívást. Az NSG diagnosztikájában kiemelkedően fontos az interdiszciplináris megközelítés, a pulmonológus, a radiológus, a sebész és a patológus közötti jó kommunikáció. Deszken a Csongrád-Csanád Megyei Mellkasi Betegségek Szakkórházában az „onkoteam” mintájára szerveződött, az interstitialis tüdőbetegségeket felölelő „fibroteam”-megbeszélések során nyílik lehetőség a klinikum, a radiológia, a laborvizsgálatok és a szövettani észleletek korrelációjára.

Anyagi támogatás: A kutatás és a tanulmány elkészítése anyagi támogatásban nem részesült.

Szerzői munkamegosztás: Valamennyi szerző részt vett a koncepció kidolgozásában, az adatgyưjjtésben és a kézirat megfogalmazásában. A cikk végleges változatát valamennyi szerző elolvasta és jóváhagyta.

Érdekeltségek: A szerzőknek nincsenek érdekeltségeik.

\section{Köszönetnyilvánítás}

Köszönjük Dezső Mihálynak, a Patológiai Intézet fotósának a szövettani képek elkészítésében nyújtott segítségét.

\section{Irodalom}

[1] Liebow AA. The J. Burns Amberson lecture - pulmonary angiitis and granulomatosis. Am Rev Respir Dis. 1973; 108: 1-18.

[2] Churg A. Pulmonary angiitis and granulomatosis revisited. Hum Pathol. 1983; 14: 868-883.

[3] Saldana MJ. Necrotizing sarcoid granulomatosis: clinicopathologic observations in 24 patients (abstract). Lab Invest. 1978; 38: 364 .

[4] Popper HH, Klemen H, Colby TV, et al. Necrotizing sarcoid granulomatosis - is it different from nodular sarcoidosis? Pneumologie 2003; 57: 268-271.

[5] Rosen Y. Four decades of necrotizing sarcoid granulomatosis: what do we know now? Arch Pathol Lab Med. 2015; 139: 252262.

[6] Agócs Á, Zibotics H, Grexa E. Necrotizing sarcoid granulomatosis: imitator in the chest. [Nekrotizáló sarcoid granulomatosis: imitátor a mellkasban.] Magy Radiol. 2004; 78: 82-84. [Hungarian]

[7] Dykhuizen RS, Smith CC, Kennedy MM, et al. Necrotizing sarcoid granulomatosis with extrapulmonary involvement. Eur Respir J. 1997; 10: 245-247.

[8] Carlens E, Hanngren A, Ivmrak B. The concomitance of feverish onset of sarcoidosis and necrosis formation in the lymph nodes. In: Iwai K, Hosoda Y (eds.) Proceedings of the 6th International Conference on Sarcoidosis. University Park Press, Baltimore, MD, 1974; pp. 409-412.

[9] Koss MN, Hochholzer L, Feigin DS, et al. Necrotizing sarcoidlike granulomatosis: clinical, pathologic, and immunopathologic findings. Hum Pathol. 1980; 11(5 Suppl): 510-519.

[10] Churg A, Carrington CB, Gupta R. Necrotizing sarcoid granulomatosis. Chest 1979; 76: 406-413.

[11] Singh N, Cole S, Krause PJ, et al. Necrotizing sarcoid granulomatosis with extrapulmonary involvement. Clinical, pathologic, ultrastructural, and immunologic features. Am Rev Respir Dis. 1981; 124: 189-192.

[12] Quaden C, Tillie-Leblond I, Delobbe A, et al. Necrotising sarcoid granulomatosis: clinical, functional, endoscopical and radiographical evaluations. Eur Respir J. 2005; 26: 778-785.

[13] Kitaichi M, Izumi T. Comparative pulmonary pathology of sarcoidosis, chronic berrylium disease and hypersentivity pneumonitis based on open lung biopsy specimen. In: International Committee On Sarcoidosis. 10th international Conference on Sarcoidosis and Other Granulomatous Disorders. Abstracts. New York Academy of Science; Baltimore, MD, 1984; p. 65.

[14] Rosen Y, Moon S, Huang CT, et al. Granulomatous pulmonary angiitis in sarcoidosis. Arch Pathol Lab Med. 1977; 101: 170174.

[15] Laszlo T. Pathology of sarcoidosis. [A sarcoidosis pathológiája.] Med Thorac. 2012; 65: 410-412. [Hungarian]

[16] Furák J, Szabó Z, Horváth T, et al. Non-intubated, uniportal, video assisted thoracic surgery [VATS] lobectomy, as a new procedure in our department. [Nem intubált, spontán légző betegnél, egy metszésből, minimálisan invazív módon elvégzett tüdőlebeny-eltávolítás mint új mútéti eljárás klinikánk gyakorlatában.] Magy Seb. 2017; 70: 113-117. [Hungarian]

(Zombori Tamás dr., Szeged, Állomás u. 2., 6701 e-mail: zomtam@gmail.com) 